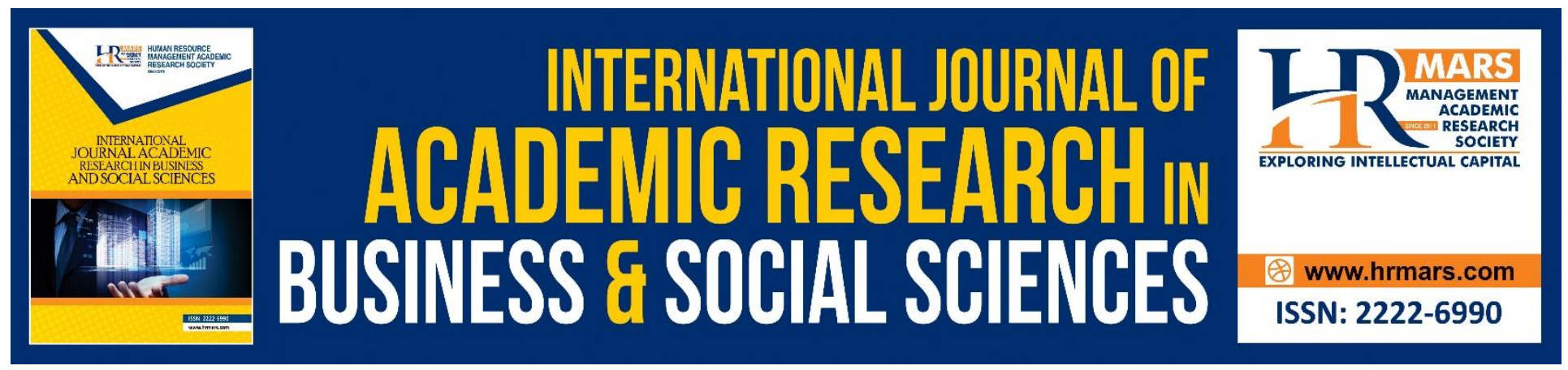

\title{
The Influence of Trust on The Intention to Perform electronic Word-of-Mouth (eWOM) and Purchase Intention Among S- Commerce Users
}

Zainika Zainudin, Hariyaty Ab Wahid, Zuraidah Zainol, Peranika Heriranto

To Link this Article: http://dx.doi.org/10.6007/IJARBSS/v10-i10/8273

DOI:10.6007/IJARBSS/v10-i10/8273

Received: 20 August 2020, Revised: 23 September 2020, Accepted: 11 October 2020

Published Online: 29 October 2020

In-Text Citation: (Zainudin et al., 2020)

To Cite this Article: Zainudin, Z., Wahid, H. A., Zainol, Z., \& Heriranto, P. (2020). The Influence of Trust on The Intention to Perform electronic Word-of-Mouth (eWOM) and Purchase Intention Among S-Commerce Users. International Journal of Academic Research in Business and Social Sciences, 10(10), 1114-1130.

Copyright: (c) 2020 The Author(s)

Published by Human Resource Management Academic Research Society (www.hrmars.com)

This article is published under the Creative Commons Attribution (CC BY 4.0) license. Anyone may reproduce, distribute, translate and create derivative works of this article (for both commercial and non-commercial purposes), subject to full attribution to the original publication and authors. The full terms of this license may be seen

at: http://creativecommons.org/licences/by/4.0/legalcode

Vol. 10, No. 10, 2020, Pg. 1114 - 1130

http://hrmars.com/index.php/pages/detail/IJARBSS

JOURNAL HOMEPAGE

Full Terms \& Conditions of access and use can be found at http://hrmars.com/index.php/pages/detail/publication-ethics 


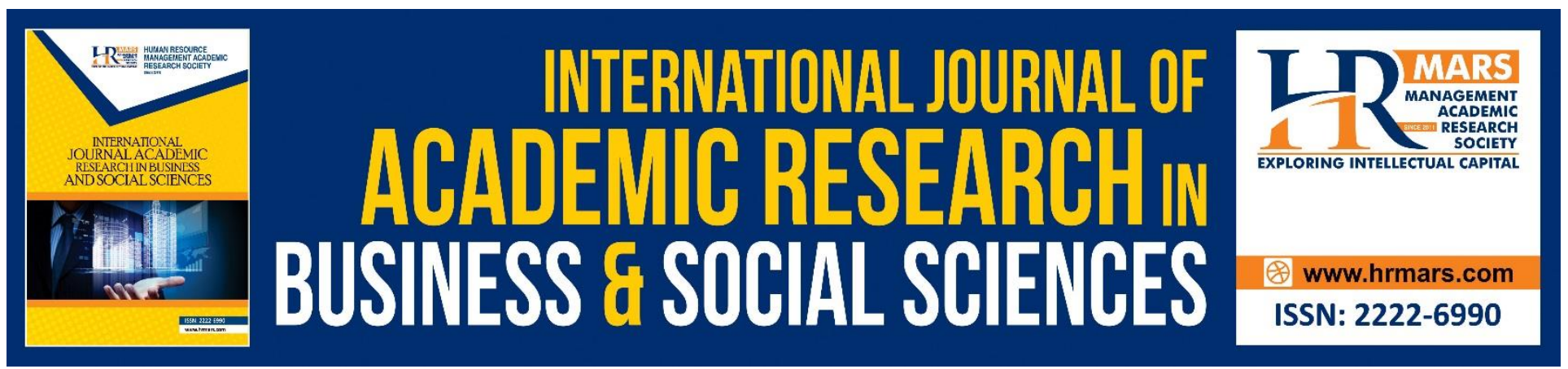

\title{
The Influence of Trust on The Intention to Perform electronic Word-of-Mouth (eWOM) and Purchase Intention Among S-commerce Users
}

\section{Zainika Zainudin, Hariyaty Ab Wahid, Zuraidah Zainol, Peranika Heriranto}

Faculty of Management and Economics, Sultan Idris Education University, 35900, Tanjung Malim, Perak, Malaysia

\begin{abstract}
Trust is outlined as one of the key components to ensure the customer's continued online transactions. However, previous studies on the influence of trust in the context of S-commerce, especially in Malaysia, are still limited. Therefore, this study aimed to determine the influence of trust on the intention to perform electronic Word-of-Mouth (eWOM) and purchase intention among Scommerce users. This study uses a quantitative approach in the form of a survey of samples. Exploratory Factor Analysis (EFA) and Cronbach's alpha analysis of pilot study data indicate that item validity and instrument reliability are satisfactory. The actual study involved 250 Facebook users following the company's fan page. The study data were analyzed using Structural Equation Modelling (SEM) analysis with Analysis Moment of Structure (AMOS) software. The findings show that the measurement model is suitable for hypothesis testing. Structural model tests show goodness of fit and prove that there are four hypotheses that are significant and positively related and one hypothesis that is not significant and negatively related. The findings show that there is a positive and significant relationship between S-commerce trust and company trust, S-trade belief with the intention to do electronic Word-of-Mouth (eWOM), the company's belief with the intention of doing electronic Word-of-Mouth (eWOM) and the positive and significant relationship between the intention to perform electronic Word-of-Mouth (eWOM) with the purchase intention. However, there is a negative and insignificant relationship between S-trade trust and purchase intention. The results of this study are also expected to provide useful input to other researchers to continue their research on trust in the context of S-commerce. These insights can also serve as references in the development of more affective and dynamic online business modules to assist entrepreneurs in building customer trust.
\end{abstract}

Keywords: Influence of Trust, S-Commerce Trust, Company Trust, Ewom Intention, Purchase Intention 
INTERNATIONAL JOURNAL OF ACADEMIC RESEARCH IN BUSINESS AND SOCIAL SCIENCES Vol. 10, No. 10, 2020, E-ISSN: 2222-6990 @ 2020 HRMARS

\section{Introduction}

The integration of E-Commerce with social media has sparked a new phenomenon in the business world known as S-Commerce (Gatautis \& Medziausiene, 2014; Esmaeili, Mardani, Mutallebi, \& Golpayegani, 2015; Linda \& Lai, 2010). S-Commerce refers to a subset of electronic commerce or in short E-Commerce (Gatautis \& Medziausiene, 2014; Lee \& Choi, 2014; Liang \& Turban, 2011; Linda \& Lai, 2010) which emerged from the string of ICT and web 2.0 development (Lai \& Turban, 2008) but more personal, interactive, and include social interaction (Rad \& Benyoucef, 2011). Linda \& Lai, (2010) highlighted one of the features that best described the S-Commerce is the viral marketing or eWOM, which occurs when a customer promotes a product or service by sharing their positive experience or feedback related to the purchase they made. This is because, this new technology has revolutionized the concept of web content contributions by giving users the opportunity to create content that makes the website more social and interconnected (Rad \& Benyoucef, 2011).

Advertising on social networking sites allow users to engage in social interactions virtually by clicking on the comments section, pressing the like button or disseminating information among their social connections. Through this interaction, indirectly, consumers are willingly showing their inclination towards a specific brand along with their personal details such as names and pictures which lead to eWOM communication. This eWOM communication relates to the eWOM intention. It further showcases the ability of social networking sites to convert and establish eWOMs' in the market (Chu \& Kim, 2011). eWOM is an effective marketing tool (Todri \& Adamopoulos, 2014). In this day and age, traditional marketing strategies are seen as less effective thus, it is more important for businesses to gain consumer trust (See-To \& Ho, 2014). The birth of the social community in SCommerce provides many advantages to both customers and businesses (Rad \& Benyoucef, 2011). Online customers can access more information from trusted parties (Rad \& Benyoucef, 2011). With a reliable and trusted information, it can help customers in reducing risks and at the same time help to boost their social confidence. Online users are active and each of them has their own string of social connections with other friends, members of different online communities, and online service provider. They can communicate, evaluate products, provide reviews and insights, participate in an online forum, share experiences and recommend products or services. This social interaction will then lead to the process of buying and selling products or services (Lai \& Turban, 2008).

\section{Problem Statement}

S-Commerce is a new phenomenon in the business world (Han, 2014). The sustainability and capabilities of S-Commerce are questionable given the purchase rate by visitors is relatively low in compared to the actual number of potential visitors to make a purchase (Lee \& Choi, 2014). Although, the time spend browsing the social networking sites are exceptional, up to this day, not much research has been conducted in regards to social networking services and their impact on the intention of purchasing. Previous studies were only limited to the S-Commerce sites in which they are purely a medium or platform for purchasing sites. However, issues related to online trading activities in social networking sites are still not fully explored (Han, 2014). Trust has often become one of the main issues raised in any form of business trading, either online trading or offline trading (physical stores) (Esmaeili et al., 2015). Trust has been outlined as a determinant in the success of ECommerce (Petrovic \& Kovacevic, 2012), the key to the main driver of social technology (DelgadoMarquez, Hurtado-Torres, \& Aragon-Correa, 2013), and key to the success of the customer-supplier 
INTERNATIONAL JOURNAL OF ACADEMIC RESEARCH IN BUSINESS AND SOCIAL SCIENCES Vol. 10, No. 10, 2020, E-ISSN: 2222-6990 @ 2020 HRMARS

relationship (Calefato, Lanubile, \& Novielli, 2015). In spite of the fact that many studies had touched on the issue of trust in virtual commercial transactions (Al-Debei, Akroush, \& Ashouri, 2015; Kwek, Dazmin Daud, Tan, Kay, \& Padzil Hassan, 2011; Kwek, Lau, \& Tan, 2010), there is still a lack of studies in the context of S-Commerce (Chow, \& Shi, 2014). Very little research has been done to consider the relationship between trust, social networking sites, and the environment of web 2.0 (GrabnerKräuter, 2010). Hence, the current developments of trade in virtual communities and social networking are worth to be appraised off (Esmaeili et al., 2015).

Social networks operate in an environment full of uncertainty in which leads to the requirement of trust when sharing personal information within the network (Grabner-Kräuter, 2010). The key question that arises is why the user of social networking is so trustworthy even when their environment is exposed to risk? (Grabner-Kräuter, 2010). The users mentioned are referred to other users, which is customers or companies. In addition, trust is also identified as one of the key element in the relationship that involves an exchange (Lien, Wu, Chen, \& Wang, 2014). Without trust, issues and problems will arise, especially when it's involve financial transactions (Esmaeili et al., 2015). The complexity and risks in making a transaction can be mitigated by the presence of trust (Lien, Wu, Chen, \& Wang, 2014). When the level of familiarity between the individual and the security mechanism of the transaction is insufficient, the trust acts as a booster to increase the confidence (Lien et al., 2014).

Trust also carried some of the generic features of which one of them is that trust can be transferred (Wang \& Vassileva, 2003). Furthermore, based on the Trust Transfer Theory in Shi \& Chow (2015), customers' trust in S-Commerce sites can be transferred to trust towards the company. Trust transfer can also be made through a proposal or suggestion (Dong, Russello, \& Dulay, 2007). Recommendations or suggestions are statements made by individuals known as proposers to one party in regard to trusting the other party with the potential of being trusted. The trusted party will then make a decision based on the recommendations presented to them (Dong et al., 2007). In this study, the proposer refers to other users who trust the company. Therefore, it is important to understand how the development of customers' trust in the S-Commerce context will affect the trust towards the company. Furthermore, the understanding of how customer trust are being develop and the process of trust transfer are still very limited in the context of S-Commerce (Shi \& Chow, 2015).

The element of eWOM on the fan page will help in building trust towards the institution which can also be referred as the individual's belief towards social structure. In the context of social networks, the institutional trust generally refers to the trust in social networking sites (See-To \& Ho, 2014). Despite that, customers' trust and confidence towards online environment is also a key factor in customer intention to disseminate eWOM (Gummerus, Liljander, Weman, \& Pihlström, 2012). Not much research has been conducted to see how web design affects the intention of eWOM (Ha \& Im, 2012). Social interactions expressed through comments, pressing the like button or sharing the post, reflect the voluntary brand tendencies among users which form an eWOM communications. While social networking sites have the potential to create eWOMs in the market, why and how eWOMs occur in an online social environment has not yet been studied. On that account, studies on social networking sites as online tools for eWOM are very much needed (Chu \& Kim, 2011). Henceforth, there may be an association between S-Commerce trust and eWOM intent.

Building customers' trust through online business is not an easy task because unlike physical stores, online business does not have the ability to allow their customer from using their senses to touch and inspect the product physically before making any decision of purchasing (Hidayanto et al., 
INTERNATIONAL JOURNAL OF ACADEMIC RESEARCH IN BUSINESS AND SOCIAL SCIENCES Vol. 10, No. 10, 2020, E-ISSN: 2222-6990 @ 2020 HRMARS

2014; Lin, Wu \& Chen, 2013). Nevertheless, with web 2.0 applications such as rankings and reviews from customers are a great solution in covering the existed barriers (Hajli, 2013; Lin, Wu \& Chen, 2013). Consumers will first search and read all the reviews posted online before placing their trust in the business in which it will then lead to the intention of purchasing (Bataineh, 2015). The combination between social elements and trust will help in enhancing the intention of purchasing through S-Commerce (Hajli, 2013). Even though, there have been some studies that show the relationship between eWOM towards the intention of purchasing (Almana \& Mirza, 2013; Rad \& Benyoucef, 2011; Erkan \& Evans, 2014; Fan \& Miao, 2012), very little research has been conducted to determine the effect of eWOM intention towards purchase intention (Lin, Wu \& Chen, 2013). The impact of eWOM towards consumer purchase intention has long been known and are hard to be dismissed. Despite that, eWOM in it's new and fresh dimension of social media is still not fully explored (Erkan \& Evans, 2014). Hence, there is still a possibility of a relationship between eWOM intent and purchase intention.

Consequently, in order to close a gap which existed based on the finding of previous research, this study presents a theory-based model which aimed to identify how customers' trust towards SCommerce is being developed and customer intention to perform eWOM and customer intention of purchasing. The research model was determined based on a customer context by looking at the relationship between trust in S-Commerce and trust towards the company which in turn will lead to the intention of performing eWOM and the intention of purchasing.

\section{Literature Reviews}

Trust is often defined as the willingness of an individual to make an exchange with the other parties which she or he believes in (Moorman, Deshpande, \& Zaltman, 1993). Mayer et al. (1995) had integrated the characteristic of public trust shared in various fields into one key point, which is trust as one party's willingness to be exposed to the action performed by another party. In commercial transaction, especially online transactions, trust plays a major role when it comes with a high level of uncertainty and risks. Therefore, trust is a critical factor in understanding customers' behaviour in the online environment (Lin, Lu, Wang, \& Wei 2011). To conclude, trust is the willingness of an individual to put their trust in others by ignoring the risk that they would have to face, especially when engaging in communication or relationship with strangers.

Trust towards E-Commerce is built on the user's past experience of doing online transactions, whereas trust in S-Commerce is built based on the other customers' past experiences in an interactive community (Shi \& Chow, 2015). Looking through the context of S-Commerce, there is an indirect transaction involving customers and companies as there are many customers who join the company S-Commerce page or fan page, simply for more information before making any decision to make a purchase (Liang, Ho, Li, \& Turban, 2011). (See-To and Ho (2014) stated that as an active member of social networking, they often disseminate information which then forms an eWOM and thus, members' trust may influence and bring a significant impact towards customers' trust in SCommerce. Based on the information, it can be concluded that trust on the S-Commerce site involves two dimensions, namely, trust in information and trust in identity. Information trustworthiness represents the customers' trust in the information posted on the S-Commerce site, including the information from the company and information from other customers (Shi \& Chow, 2015). While trust in identity represents the customers' trust in other members of the S-Commerce page which is also based on trust towards other customers. 
INTERNATIONAL JOURNAL OF ACADEMIC RESEARCH IN BUSINESS AND SOCIAL SCIENCES Vol. 10, No. 10, 2020, E-ISSN: 2222-6990 @ 2020 HRMARS

Trust in the E-Commerce platform will lead to trusting the seller (Chen, Huang, Davison, \& Hua, 2016). In the context of this study, the same situation applies to the belief that trust in SCommerce will affect the trust towards the company. Shi and Chow (2015) outlined that trust towards the company is made up three main factors, namely, the welfare factor in which the customer believes that the company cares about their customer and is acting well according to the customer's needs and requirements, competency factor in which the company has the ability to meet all the customer's requirements and last but not least, the factor of integrity where the company is transparent and able to fulfil their promises.

Next, eWOM refers to the exchange of knowledge by users which are solely conducted in an online environment ( $\mathrm{Wu} \& \mathrm{Wang}, 2011$ ). This exchange is directly related to the loyalty of the customer, thus provide an advantage to the company. Abrantes, Seabra, Lages, and Jayawardhena, (2013) further defined eWOM as the informal supply and reception of information, advice or views on products or services through social networking sites which existed in the electronic environment. Whereas, Teng, Khong, Goh, and Chong, (2014) had suggested eWOM as any positive or negative statement made by a potential customer, real or existed customer, or customer who tell you about a product or company that can be viewed by other users or institutions through the internet. Referring to these statements, the intention of eWOM can be referred to a situation where SCommerce users have the will and intention to convey either positive or negative information and to make a recommendation of the company fan page to other online users.

Moving on, the intention of purchasing refers to the consumer's intention to purchase a product or service (Lin, Wu \& Chen, 2013). In this situation, consumers are willing to engage in an online transaction (Pavlou, 2003). Purchase intentions are classified as a component of consumers' cognitive behavior towards how an individual intends to buy a brand (Kwek, Lau, \& Tan, 2010). Therefore, purchase intent can be defined as a situation where S-Commerce users are willing to engage in an online transaction through the company's fan page in the future.

\section{Research Methodology}

The researcher had opted to use a quantitative approach with the sample surveys method. Data obtained from primary data were then analyzed in this research. The collection of the data was done using a questionnaire that was uploaded into the Google Doc software. The questionnaire was then distributed online by using links that can be shared on Facebook application. A total of 250 respondents was involved in this research which was selected using a simple random sampling with cluster sampling technique involving Facebook users who follows the company Facebook page or fan page. The questionnaire items used to measure the constructs in this research were adapted and modified from the following studies, namely by Shi and Chow (2015); Hidayanto, Herbowo, Budi, and Sucahyo (2014); Bataineh (2015) and last by not least, research by $\mathrm{Ha}$ and Im (2012). The questionnaire was divided into two main sections, Part $A$ and Part B. Part A includes 30 items of questions which aimed at understanding the impact of trust in S-Commerce and trust towards the company on eWOM intention and purchase intention. And, Part B contains only nine items of questions that are related to the respondents' personal background information. The collected data were then analyzed using Structural Equation Modelling (SEM) to test the five hypotheses that have been proposed. 
INTERNATIONAL JOURNAL OF ACADEMIC RESEARCH IN BUSINESS AND SOCIAL SCIENCES Vol. 10, No. 10, 2020, E-ISSN: 2222-6990 @ 2020 HRMARS

\section{Research Findings}

The respondents' profiles consisted of followers of the company's fan page on Facebook which was randomly chosen. A total of 250 respondents had answered the posted questionnaire. Table 1 shows the background data of the chosen respondents. In accordance with the data in Table 1, the sample of the study was mainly dominated by female respondents with a total of 57.6 percent from the overall sample collected. The majority of the respondents are Malay which accounted for a total of 91.2 percent. And the majority of the selected respondents were Muslims, that is by 92.0 percent. Next, a greater number of respondents were in a range of 25 to 29 years old with 32.0 percent. Most of the respondents, with a recorded figure of 43.6 percent had a diploma education, while in the occupation category, the highest percentage recorded by the respondents were of among students by 30.4 percent. In addition, 26.4 percent of the respondents were from higher education institutions. The data also show that 72.0 percent of the respondents use social media for 6 to 7 days a week. Meanwhile, 59.2 percent of respondents have been on social media sites in a range of 19 to 24 months.

Table 1: Profile Analysis of the Respondents.

\begin{tabular}{|c|c|c|c|}
\hline Item & Category & Frequency & Percentage \\
\hline \multirow[t]{2}{*}{ Gender } & Male & 106 & 42.4 \\
\hline & Female & 144 & 57.6 \\
\hline \multirow[t]{4}{*}{ Race } & Malay & 228 & 91.2 \\
\hline & Chinese & 11 & 4.4 \\
\hline & Indian & 8 & 3.2 \\
\hline & Others & 3 & 1.2 \\
\hline \multirow[t]{5}{*}{ Religion } & Islam & 230 & 92.0 \\
\hline & Buddha & 8 & 3.2 \\
\hline & Hindu & 8 & 3.2 \\
\hline & Christian & 3 & 1.2 \\
\hline & Others & 1 & 0.4 \\
\hline \multirow[t]{4}{*}{ Age } & $15-19$ years old & 45 & 18.0 \\
\hline & 20-24 years old & 49 & 19.6 \\
\hline & $25-29$ years old & 80 & 32.0 \\
\hline & 30-34 years old & 76 & 30.4 \\
\hline \multirow[t]{4}{*}{ Education } & Secondary School & 29 & 11.6 \\
\hline & Diploma/ Certificate & 109 & 43.6 \\
\hline & Bachelor Degree & 96 & 38.4 \\
\hline & PhD/Master & 16 & 6.4 \\
\hline \multirow[t]{7}{*}{ Pekerjaan } & Student & 76 & 30.4 \\
\hline & Technical and support staff & 44 & 17.6 \\
\hline & Business Owner & 11 & 4.4 \\
\hline & Middle Management & 24 & 9.6 \\
\hline & Top Management & 2 & 0.8 \\
\hline & Professional & 38 & 15.2 \\
\hline & Others & 55 & 22.0 \\
\hline Job Institution & School & 42 & 16.8 \\
\hline
\end{tabular}


INTERNATIONAL JOURNAL OF ACADEMIC RESEARCH IN BUSINESS AND SOCIAL SCIENCES Vol. 10, No. 10, 2020, E-ISSN: 2222-6990 @ 2020 HRMARS

\begin{tabular}{llcc} 
& Higher Education Institution & 66 & 26.4 \\
& Company & 23 & 9.2 \\
& Private Organization & 36 & 14.4 \\
& Government Agency & 64 & 25.6 \\
& Others & 19 & 7.6 \\
The frequency of & 0-1 day & 12 & 4.8 \\
using social & 2-3 days & 17 & 6.8 \\
media in a week. & 4-5 days & 41 & 16.4 \\
The duration of & 6-7 days months & 180 & 72.0 \\
following social & 7-12 months & 31 & 12.4 \\
media sites & 13-18 months & 44 & 17.6 \\
& 19-24 months & 27 & 10.8 \\
\hline
\end{tabular}

The preliminary analysis had involved an analysis of missing values and SEM assumptions in which include normality, outliers and multicollinearity. There were 26 outliers that were excluded from the 250 respondents. The remaining 224 respondents were used for the subsequent analysis. Ensuing, SEM analysis was performed using AMOS software which involved two stages. The first stage is testing the measurement model. The findings show that the measurement model as shown in Figure 1 is consistent with the data and able to verify the validity and reliability of the constructs to be used in the hypothesis testing. 
INTERNATIONAL JOURNAL OF ACADEMIC RESEARCH IN BUSINESS AND SOCIAL SCIENCES Vol. 10, No. 10, 2020, E-ISSN: 2222-6990 @ 2020 HRMARS

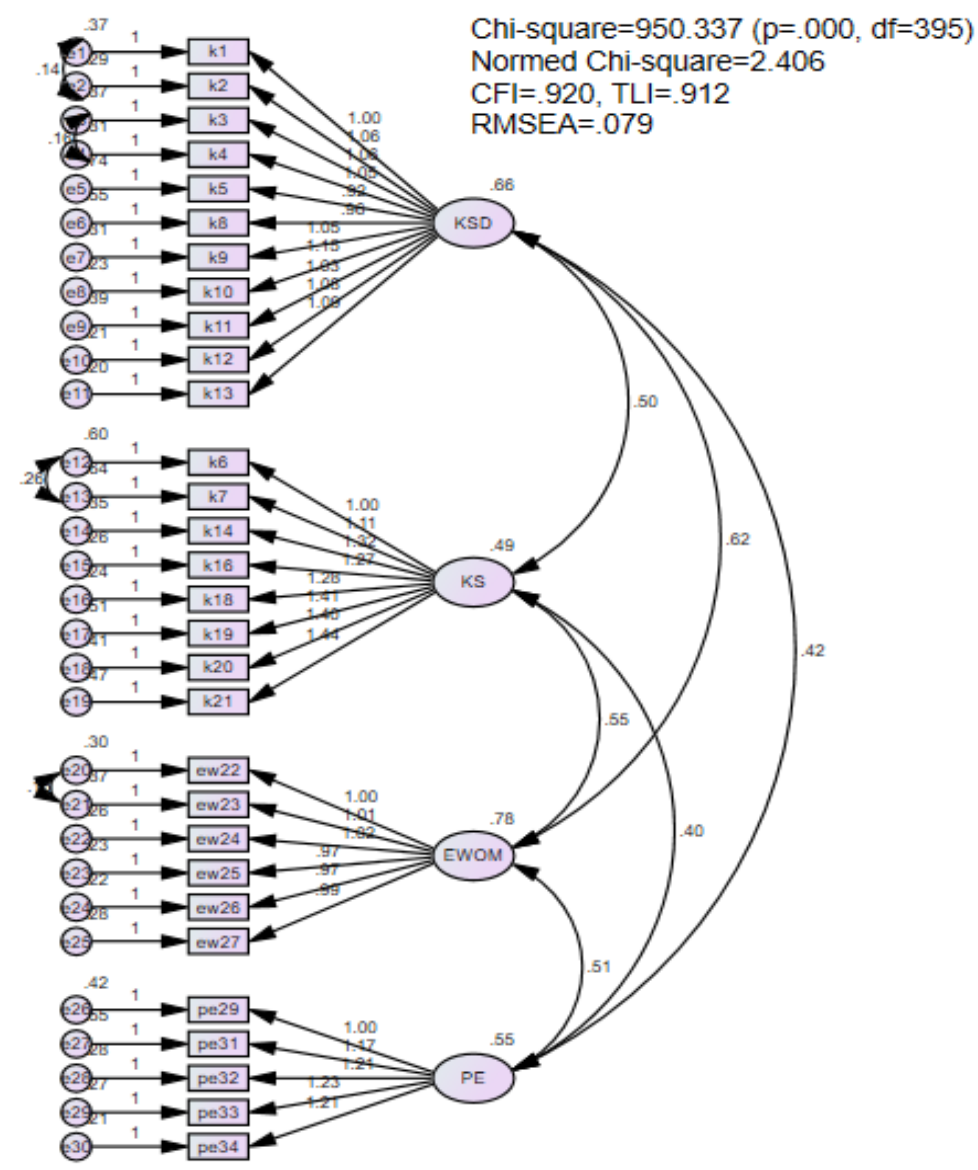

Figure 1 : Measurement Model

Table 1 below shows the significant value of chi square $\left(\chi^{2}\right)$ which is $950.337(d f=395, p<0.05)$, with normed value $\chi^{2}$ recorded is 2.406 . Whereas CFI value is 0.920 and RMSEA value is 0.079 . All of these recorded values have met the specified criteria of value level. Therefore, the measurement model is acceptable and appropriate for the assessment of validity and reliability.

Table 1: Goodness-of-fit Index

\begin{tabular}{lllll}
\hline GOF Statistic & $\chi^{2}(\mathrm{df}, \mathrm{p})$ & $\chi^{2} / \mathrm{df}$ & CFI & RMSEA \\
\hline $\begin{array}{l}\text { Measurement } \\
\text { model }\end{array}$ & $950.337(395,0.000)$, & 2.406, & 0.920 & 0.079 \\
* Accepted value & Significant at $\alpha=0.05$ & $1-5$ & $>0.9$ & $<0.08$ \\
\hline based on Hair et al., (2010) and Garson (2012a) & &
\end{tabular}

Based on Table 2, construct reliability (CR) is in the range of 0.916 to 0.957 , while AVE value is in the range of 0.653 to 0.738 . The CR value is greater than 0.7 and the AVE value is greater than 0.5 , while the standardized factor loadings for all items are significant and greater than 0.7 . Hence, convergent validity proves that all items are positively related to one another. The corresponding inter-construct correlations (IC) value for each construct is less than 0.9 . Thus, discriminant validity is also supported, 
INTERNATIONAL JOURNAL OF ACADEMIC RESEARCH IN BUSINESS AND SOCIAL SCIENCES

Vol. 10, No. 10, 2020, E-ISSN: 2222-6990 @ 2020 HRMARS

which proves that items are more common to their respective constructs than to other constructs. By achieving the fit model and the validity and reliability of the construct, thus the model is suitable for hypothesis testing.

Table 2: Evaluation of Measurement Models

\begin{tabular}{lllllll}
\hline \multirow{2}{*}{$\begin{array}{l}\text { Construct } \\
\text { (Loadings) }\end{array}$} & \multicolumn{4}{l}{ Inter-construct correlations (IC) } & AVE & CR \\
\cline { 2 - 7 } & KSD & KS & EWOM & PE & & \\
\hline KSD & 1 & & & & 0.671 & 0.957 \\
KS & $0.882^{* * *}$ & 1 & & 0.653 & 0.937 \\
EWOM & $0.871^{* * *}$ & $0.886^{* * *}$ & 1 & & 0.738 & 0.944 \\
PE & $0.705^{* * *}$ & $0.764^{* * *}$ & $0.774^{* * *}$ & 1 & 0.686 & 0.916 \\
\hline
\end{tabular}

Note:

$\mathrm{AVE}=$ average variance extracted $=\Sigma$ squared loadings $/ \mathrm{n}$, $\mathrm{CR}=$ construct reliability $=(\Sigma \text { loading })^{2} /\left[(\Sigma \text { loading })^{2}+\Sigma\left(1\right.\right.$-factor loading $\left.{ }^{2}\right]$

From the structural model testing, it shows that Goodness-of-fit indices are within the acceptable range. Table 3 and Figure 2 show the significant value of chi square $\left(\chi^{2}\right)$ which is $957.711(d f=396$, $\mathrm{p}<0.05$ ), the normed value $\chi^{2}$ is 2.418, CFI 0.919, TLI 0.911, and RMSEA is 0.080 . Henceforth, comprehensively, model fit is recommended for the hypothesis testing.

Table 3: Goodness-of-fit Index (After re-stated)

\begin{tabular}{|c|c|c|c|c|c|}
\hline GOF Statistic & $\chi^{2}(d f, p)$ & $\chi^{2} / \mathrm{df}$ & $\mathrm{CFI}$ & TLI & RMSEA \\
\hline $\begin{array}{l}\text { Measurement } \\
\text { model }\end{array}$ & $\begin{array}{l}\text { 957.711(396, } \\
0.000)\end{array}$ & 2.418 & 0.919 & 0.911 & 0.080 \\
\hline Accepted value & $\begin{array}{l}\text { Significant at } \alpha= \\
0.05\end{array}$ & $1-5$ & $>0.9$ & $>0.9$ & $<0.08$ \\
\hline
\end{tabular}

Based on Table 4 and Figure 2, the $R^{2}$ value of the first equation is 0.78 , representing 78 percent of the total variance, in which the trust towards the company (KS) is influenced by the trust in the SCommerce (KSD). Furthermore, the effect of the trust in $S$-Commerce $(\beta=0.883, p<0.001)$ on the trust towards the company is significant. Therefore, $\mathrm{H} 1$ is supported. For the second equation, it shows that the value of $R^{2}$ is 0.828 , representing 82.8 percent of the total variance in eWOM intentions that can be explained by trust in the S-Commerce (KSD) and trust towards the company (KS). The effect of trust in the $S$-Commerce and towards the company on eWOM intentions is significant and positive with $(\beta=0.376, p<0.001)$ and $(\beta=0.56, p<0.001)$ respectively. Thus, $\mathrm{H} 2$ and $\mathrm{H} 3$ are supported. Lastly, the $R^{2}$ value of the third equation is 0.616 , which represents 61.6 percent of the variance in the intention of purchasing (PE) that is influenced by the trust towards the company (KS) and eWOM intentions. The effect of trust in the company $(K S)$ is not significant and negative $(ß=-0.116, p>0.001)$, while the effect of eWOM intention (EWOM) is significant and positive ( $\beta=0.682, p<0.001$ ). Therefore, $\mathrm{H} 4$ is not supported while $\mathrm{H} 5$ is supported. Overall, from the four relationships that are proposed in the research framework, namely $\mathrm{H} 1, \mathrm{H} 2, \mathrm{H} 3$, and $\mathrm{H} 5$ are significant and supported, while $\mathrm{H} 4$ is not significant and is not supported. 
INTERNATIONAL JOURNAL OF ACADEMIC RESEARCH IN BUSINESS AND SOCIAL SCIENCES Vol. 10, No. 10, 2020, E-ISSN: 2222-6990 @ 2020 HRMARS

Table 4: Hypothesis Testing Formulas for Direct Effects.

\begin{tabular}{|c|c|c|c|c|}
\hline Hypothesized path & $\begin{array}{l}\text { Expected } \\
\text { direction }\end{array}$ & $\begin{array}{l}\text { Standardized } \\
\text { Estimate }\end{array}$ & $\begin{array}{l}t- \\
\text { value }\end{array}$ & Results \\
\hline \multicolumn{5}{|l|}{$\mathrm{R}^{2}(\mathrm{KS})=0.78$} \\
\hline $\mathrm{H} 1: \mathrm{KSD} \rightarrow \mathrm{KS}$ & + & $0.883^{* * *}$ & 10.148 & Supported \\
\hline \multicolumn{5}{|l|}{$\mathrm{R}^{2}(\mathrm{EWOM})=0.828$} \\
\hline $\mathrm{H} 2: \mathrm{KSD} \rightarrow \mathrm{EWOM}$ & + & $0.376 * * *$ & 4.405 & Supported \\
\hline H3 : KS $\rightarrow$ EWOM & + & $0.56 * * *$ & 5.455 & Supported \\
\hline \multicolumn{5}{|l|}{$R^{2}(P E)=0.616$} \\
\hline $\mathrm{H} 4: \mathrm{KSD} \rightarrow \mathrm{PE}$ & - & $0.116 n s$ & 2.853 & Not \\
\hline H5 : EWOM $\rightarrow$ PE & + & $0.682 * * *$ & 3.564 & $\begin{array}{l}\text { supported } \\
\text { Supported }\end{array}$ \\
\hline $\begin{array}{l}\text { Goodness-of-fit stat } \\
0.919, \text { RMSEA }=0.08\end{array}$ & - & $306 n-0$ & & $=2.418, \mathrm{CFI}=$ \\
\hline
\end{tabular}

Note:

KSD - trust on S-Commerce, KS - trust on company, EWOM - electronic word-of- mouth intentions,

PE - purchase intentions

Acceptable values: significant $\chi^{2}, \chi^{2} / d f$ within $1-5, \mathrm{CFI}>0.9, \mathrm{RMSEA}<0.08$

$* * * \mathrm{p}<0.001, \mathrm{~ns}$ not significant

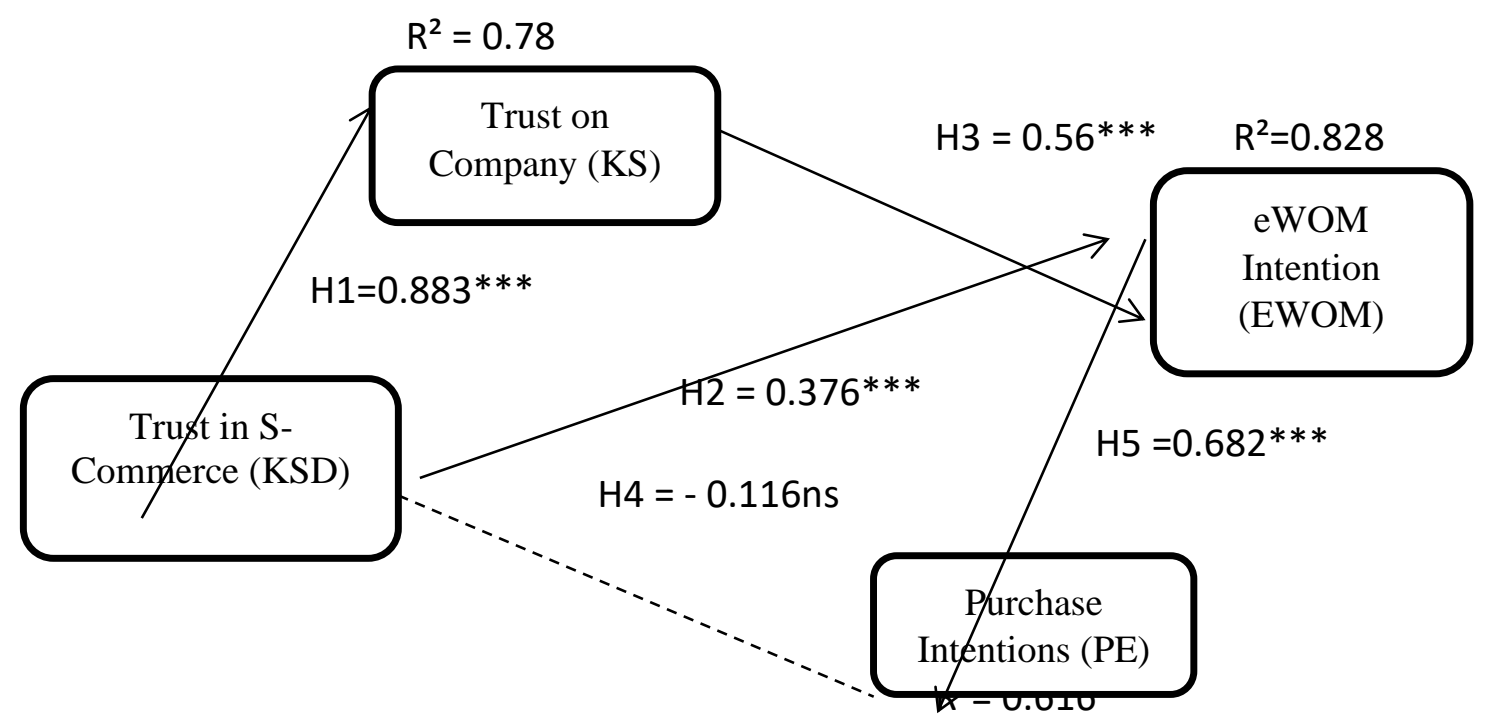

---- significantly related

- - - not significantly related

$* * * p<0.001$

ns not significant
Chi-square $=957.711(p=.000, d f=396)$

Normed chi-square $=2.418$

$\mathrm{CFI}=.919, \mathrm{TLI}=.911$

RMSEA $=.080$

Figure 2: Results of the Proposed Structural Model Test 
INTERNATIONAL JOURNAL OF ACADEMIC RESEARCH IN BUSINESS AND SOCIAL SCIENCES Vol. 10, No. 10, 2020, E-ISSN: 2222-6990 @ 2020 HRMARS

\section{Discusions and Conclusion}

Firstly, the findings shows that there is a significant relationship between trust in the S-Commerce and trust towards the company. This finding is in line with the findings from Shi and Chow (2015) which showed that the trust in the information uploaded by the company's brand page and the trust of other members in the same company's brand page is significant to the trust towards the company. Hajli and Khani (2013) had stated, in which the current trend is that the customer will become a follower in the S-Commerce sites in order to obtain product-related information from other customers. The findings are also consistent with the findings made by Chen et al., (2016) who had suggested that the consumer trust in the S-Commerce platform will influence the trust towards the sellers. Gummerus, Liljander, Weman, and Pihlström, (2012) have also shown that the brand community or the company in Facebook application will help to connect other followers with the brand, more than the relationships between the followers itself. This indicates that unknowingly, the community or followers that are participating in the S-Commerce site of a company has actually connected or strengthened their relationships with other followers or users on the campany's fan page when the provision and dissemination of information had taken place through eWOM.

Secondly, the findings also indicate that there is a significant relationship between trust in SCommerce and the intention to perform electronic Word-of-Mouth (eWOM). This finding is in line with the findings by Gummerus, Liljander, Weman, and Pihlström, (2012) ; Choi and Scott (2013) ; and Chu and Kim (2011) which have shown that users' trust towards other followers of the fan page will influence the willingness and desires of S-Commerce users to convey positive information and eventually will recommend the company's fan page to other users. The followers of the company's fan page have an advantage of connecting other members or followers with the company more than the relationship between the follower itself. The transmission and dissemination of information is being conveyed through social interactions, such as by commenting, pressing the like button or sharing posts that voluntarily reflect the consumers' inclination for a specific brand in which will form an eWOM communications (Ha \& Im, 2012). Additionally, as suggested by Cheung, Lee, and Rabjohn (2008), when an individual put their trust on other people and start considering themselves as part of the community, they are more likely to disseminate an eWOM. Trust that is being emphasized is the trust towards others in social networks. The eWOM can be measured by three aspects : seeking a viewpoint, giving a viewpoint and disseminating a viewpoint. However, eWOM intention in this study is to show that S-Commerce users will be a viewpoint seeker before focusing their attention as a contributor and disseminator of viewpoints. An interactive environment of social networking sites enables the user to play a variety of roles such as a seeker, a contributor, and even a disseminator. Eventually, the user will voluntarily share their information about a certain brand with other users in the online community.

eWOM is not necessarily performed by customers who had made their purchases, it can also be disseminated by potential customers. In other words, S-Commerce users who have never made any purchases from the company's fan page are also likely to become customers and potentially will start spreading eWOM when trust in S-Commerce had existed. The existence of trust in the SCommerce site is influence by the information seen on the fan page of the company as well as the trust of other followers towards the company's fan page. Consumers often make an assumption that social media always provide authentic information when searching for brand-related information compared to a content posted by the seller in a traditional advertising methods. This is because activities such as sharing of information and interaction that exists between followers on the fan page 
INTERNATIONAL JOURNAL OF ACADEMIC RESEARCH IN BUSINESS AND SOCIAL SCIENCES Vol. 10, No. 10, 2020, E-ISSN: 2222-6990 @ 2020 HRMARS

is free without any limitation and restrictions. Its provide them with various information that are important when making the decision to purchase. In other words, users may express their experience of the product or service provided through the comment section on the fan page in a transparent manner without any intervention or ceorcion by the company. Other than that, users are open to have an interaction with other followers without being in control or known by the company's fan page. This matter has further strengthened users' trust towards the fan page. This trust will further encourage users to disseminate positive information about the fan page they had visited or is following to other users or friends. This dissemination and recommendations are made directly or indirectly by the user. Some users are even willing to share information by uploading them on the fan page they are following or visited. Meanwhile, when a Facebook user clicks on the like button on the company's fan page, automatically any activity or reaction of following the fan page will also appear on the news feed of other users which are connected through a connection called 'Friend'. This term of 'Friend' on Facebook allows people who have been accepted as your friend to be able to view your activity through their news feed. This refers to the user behavior that represent their intention of performing eWOM.

Thirdly, the findings also show that there is a significant relationship between trust towards the company and the intention of performing an electronic Word-of-Mouth (eWOM). This finding is in line with the findings made by Shi and Chow (2015) and Achmad Nizar Hidayanto et al. (2014) who have proven that trust towards the company has a significant impact on eWOM intentions. Consumers are prone to take into consideration the company's reputation as an important factor before putting their trust and making a decision to purchase a product or service provided. This situation shows that the reputation of the company in the users' eyes are shaped by the information shared by other followers on the company's fan page. S-Commerce users will build their trust towards the company through positive comments or information uploaded by other followers on the fan page. Increased levels of trust will cause individuals to engage in other interactions that require more trust. This other interaction refers to the trust decisions or actions taken by the user. Trust decisions refer to the willingness of one party to put their trust on another party or subject in a situation along with a sense of security and awareness of the potentially negative circumstances that may exist (Leila Esmaeili et al., 2015). Before the user has a desire or willingness to share information with other users, first and foremost, the user must have complete trust and unwavering confidence towards the company's fan page. Customer loyalty towards the company will only exist when consumers start to trust the company in which will lead to the occurence of eWOM (Wu \& Wang, 2011). Only then the consumer will have the willingness to exchange knowledge and information without being influenced by either party. This indicates that indirectly, the user has developed an intention of performing an eWOM.

Fourthly, the research also found that there was no significant relationship between consumers' trust in S-Commerce and purchase intention. This finding is actually in contrast with the findings by Abdul Rahman Zahari et al. (2013); Han (2014); Suryaningsih, Hadiwidjojo, Rohman, and Sumiati (2014); Mahmood Hajli (2013); Zhang, Lee, and Fang (2013) and Weisberg et al. (2011) which suggested that there is a positive relationship between trust in social networks and purchase intention. However, this finding is in line with other findings made by Sukrat, Papasratorn, and Chongsuphajaisiddhi (2015) which proposed that trust in Facebook does not influence the intention of buying an organic rice. The same situation is being applied in this research, where it shows that trust in Facebook represents the trust in S-Commerce. This means that consumers' trust in S- 
INTERNATIONAL JOURNAL OF ACADEMIC RESEARCH IN BUSINESS AND SOCIAL SCIENCES Vol. 10, No. 10, 2020, E-ISSN: 2222-6990 @ 2020 HRMARS

Commerce has no effect on purchase intention. On the contrary, purchase intentions will only exist when consumers start to have a trust that the product being put on sale has met the consumer expectations and requirements, in which after purchasing the product, they will be satisfied with the quality of the product. This refers to the consumer satisfaction when using a product of a specific brand. Consumers who are comfortable and have their trust in the product from a certain brand will not easily replace the product from another brand. As such, the brand also plays an important role in securing a product identity. A brand must be able to give their users a positive impression and confidence that they are truly trustworthy. By building the trust towards the company, people will have the confidence that the products they produce will meet their needs and desires (Danisa, Istiyanto, \& Ardyana, 2017).

Lastly, the findings also indicate that there is a significant relationship between the intention of performing an electronic Word-of-Mouth (eWOM) and the intention of purchasing. This finding has been supported by Syafaruddin, Suharyono, Kumadji (2016); Xu (2010); Almana and Mirza (2013); Rad and Benyoucef (2011) and Wardiyastuti (2017) which prove that there is a significant effect of eWOM communication on purchase intentions. eWOM communication is similar to eWOMs intention. eWOMs communication through dissemination of information and suggestions are builtin through reading reviews and recommendations received from the online community. When SCommerce users start to read reviews and recommendations from other followers, it is inevitable that users have instilled the perception of the fan page in their minds. The built-in perception will then influence the user to make a purchase from the company's fan page. S-Commerce users will also impel to have the intention of purchasing, although, in reality, they have never made any dealings or transactions with the company's fan page. This is because the reviews and recommendations from other users in the company's fan page will help in shaping the trust of other S-Commerce users' have towards the company, thus allowing consumers to continue to disseminate positive information based on the information they receive from other users. In normal circumstances, consumers tend to look for information as much as they can before making any decision to purchase a product or a service. The information obtained will help to boost consumer confidence in putting their trust towards the company. Users who have read all the reviews, recommendations and other information obtained online will more likely to be encouraged to write positive information based on what they have read and gained from an online review. Indirectly, the next user will make a suggestion on a company's fan page that they trust based on their reading to other users. This indicates that all the reviews and positive information that can be found on the company's fan page will influence the users to perform eWOM intentions, which in turn will lead to the purchase intention in the future.

In conclusion, trust is a very important factor in shaping purchase intention and eWOM intention. However, consumer trust towards the company is more important than consumer trust in S-Commerce when shaping purchase intentions. Hence, the company should always strive to maintain a good image starting from an aspect such as product manufacturing till providing the best service in any transaction on the S-Commerce site. The consumer's attitude in this new era of globalization where everything is at your fingertips, they are more willing to try new things and dare to take on more risks in every matter. It is an aspect that should be taken seriously in improving the online business market among S-Commerce users. There are already some changes that start to appear in consumer attitudes and notions, in which trust in the company is much more important rather than their trust towards the S-Commerce site or any sale platforms. Rationally, trust in the SCommerce site is less important because S-Commerce site is just a medium where the consumer will 
INTERNATIONAL JOURNAL OF ACADEMIC RESEARCH IN BUSINESS AND SOCIAL SCIENCES Vol. 10, No. 10, 2020, E-ISSN: 2222-6990 @ 2020 HRMARS

make their purchase of a product from a certain company. S-Commerce site is only a platform or a medium that connects companies and consumers, it does not involve risk-taking activities such as the exchange of personal information or account numbers which can implicate users with significant risks if it is not being handled correctly. Therefore, trust towards the company is more important and has an impact on purchase intentions among S-Commerce users.

\section{Corresponding Author}

Zainika Zainudin

Universiti Pendidikan Sultan Idris, Malaysia

Email: zainika.zainudin@gmail.com

\section{References}

Abrantes, J. L., Seabra, C., Lages, C. R., \& Jayawardhena, C. (2013). Drivers of in-group and out-ofgroup electronic word-of-mouth (eWOM). European Journal of Marketing, 47(7), 1067-1088. DOI 10.1108/03090561311324219

Al-Debei, M. M., Akroush, M. N., \& Ashouri, M. I. (2015). Consumer attitudes towards online shopping: The effects of trust, perceived benefits, and perceived web quality. Internet Research, 25(5), 707-733. http://doi.org/10.1108/IntR-05-2014-0146

Almana, A. M., \& Mirza, A. A. (2013). The Impact of Electronic Word of Mouth on Consumers ' Purchasing Decisions. International Journal of Computer Applications, 82(9), 23-31.

Bataineh, A. Q. (2015). The Impact of Perceived e-WOM on Purchase Intention: The Mediating Role of Corporate Image. International Journal of Marketing Studies, 7(1), 126-137. http://doi.org/10.5539/ijms.v7n1p126

Calefato, F., Lanubile, F., \& Novielli, N. (2015). The Role of Social Media In Affective Trust Building In Customer-Supplier Relationships. Electron Commer Res 15, 453-482. DOI 10.1007/s10660015-9194-3

Chow, W. S., \& Shi, S. (2014). Understanding Consumer Trust in Social Commerce Websites. PASIC 2014 Proceedings. Paper 94.

Chu, S.-C., \& Kim, Y. (2011). Determinants of consumer engagement in electronic word-of-mouth (eWOM) in social networking sites. International Journal of Advertising, 30(1), 47. http://doi.org/10.2501/IJA-30-1-047-075

Delgado-Marquez, B. L., Hurtado-Torres, N. E., \& Aragon-Correa, J. A. (2013). On the Measurement of Interpersonal Trust Transfer: Proposal of Indexes. Soc Indic Res, 113, 433-449. http://doi.org/10.1007/s11205-012-0103-z

Dong, C., Russello, G., \& Dulay, N. (2007). Trust Transfer in Distributed Systems. International Federation for Information Processing, 238, 17-29.

Erkan, I., \& Evans, C. (2014). The impacts of electronic word of mouth in social media on consumer's purchase intentions. International Conference on Digital Marketing, 11. Retrieved from http://v-scheiner.brunel.ac.uk/bitstream/2438/9706/1/Fulltext.pdf

Esmaeili, L., Mardani, S., Mutallebi, M., \& Golpayegani, S. A. H. (2015). Studying the Affecting Factors on Trust in Social Commerce. International Journal Of Advanced Studies In Computer Science and Engineering, 4(6), 41-46. 
INTERNATIONAL JOURNAL OF ACADEMIC RESEARCH IN BUSINESS AND SOCIAL SCIENCES

Vol. 10, No. 10, 2020, E-ISSN: 2222-6990 @ 2020 HRMARS

Fan, Y. W., \& Miao, Y. F. (2012). Effect of Word-of-Mouth on Consumer Purchase Intention: The Perspective of Gender Differences. International Journal of Electronic Business Management, 10(3), 175-181. Retrieved from

http://search.ebscohost.com/login.aspx?direct=true\&db=bth\&AN=83524833\&site=ehost-live

Gatautis, R., \& Medziausiene, A. (2014). Factors Affecting Social Commerce Acceptance in Lithuania. Procedia - Social and Behavioral Sciences, 110(0), 1235-1242.

http://doi.org/http://dx.doi.org/10.1016/j.sbspro.2013.12.970

Grabner-Kräuter, S. (2010). Toward A Better Understanding Of Trust In Web 2.0. AMA Winter Educators' Conference Proceedings, 313-322.

Gummerus, J., Liljander, V., Weman, M., \& Pihlstrom, M. (2012). Customer Engagement In A Facebook Brand Community. Management Research Review 35(9), 857-877. DOI 10.1108/01409171211256578

Ha, Y., \& Im, H. (2012). Role of web site design quality in satisfaction and word of mouth generation. Journal O Service Management, 23(1), 79-96. http://doi.org/10.1108/09564231211208989

Hajli, M. (2013). A research framework for social commerce adoption. Information Management \& Computer Security, 21(3), 144-154. http://doi.org/10.1108/IMCS-04-2012-0024

Han, M.-C. (2014). How Social Network Characteristics Affect Users' Trust and Purchase Intention. International Journal of Business and Management, 9(8), 122-132. Retrieved from http://www.ccsenet.org/journal/index.php/ijbm/article/view/35136 \n<Go to ISI>://WOS:000317916100001 \nhttp://jtr.sagepub.com/cgi/doi/10.1177/0047287512467699

Hidayanto, A. N., Herbowo, A., Budi, N. F. A., \& Sucahyo, Y. G. (2014). Determinant Of Customer Trust On E-Commerce And Its Impact To Purchase And Word Of Mouth Intention: A Case Of Indonesia. Journal of Computer Science 10, 10(12), 2395-2407. http://doi.org/10.3844/jcssp.2014.2395.2407

Kwek, C. L., Dazmin Daud, Tan, H. P., Kay, H. K., \& Hassan, P. (2011). Perceived Risk, Perceived Technology, Online Trust for the Online Purchase Intention in Malaysia. International Journal of Business and Management, 6(6), 167-182. http://doi.org/10.5539/ijbm.v6n6p167

Kwek, C. L., Lau, T. C., \& Tan, H. P. (2010). The Effects of Shopping Orientations , Online Trust and Prior Online Purchase Experience toward Customers ' Online Purchase Intention. International Business Research, 3(3), 63-76. Retrieved from http://ccsenet.org/journal/index.php/ibr/article/viewFile/6506/5122

Lee, H., \& Choi, J. (2014). Why do people visit social commerce sites but do not buy? The role of the scarcity heuristic as a momentary characteristic. KSII Transactions on Internet and Information Systems, 8(7), 2383-2399.

Liang, T. P., \& Turban, E. (2011). Introduction to the Special Issue Social Commerce: A Research Framework for Social Commerce. International Journal of Electronic Commerce 16(2), 5-13. DOI 10.2753/JEC1086-4415160201

Liang, T.-P., \& Turban, E. (2011). Introduction to the Special Issue Social Commerce: A Research Framework for Social Commerce. International Journal of Electronic Commerce, 16(2), 5-14. http://doi.org/10.2753/JEC1086-4415160201

Lien, C. H., Wu, J. J., Chen, Y.,H., \& Wang, C, J. (2014). Trust Transfer and The Effect Of Service Quality On Trust In The Healthcare Industry. Managing Service Quality 24(4), 399-416. DOI 10.1108/MSQ-11-2013-0255. 
INTERNATIONAL JOURNAL OF ACADEMIC RESEARCH IN BUSINESS AND SOCIAL SCIENCES

Vol. 10, No. 10, 2020, E-ISSN: 2222-6990 @ 2020 HRMARS

Lin, C., Wu, Y.-S., \& Chen, J.-C. V. (2013). Electronic Word-of-Mouth: The Moderating Roles of Product Involvement and Brand Image. Proceedings of 2013 International Conference on Technology Innovation and Industrial Management, 29-47. Retrieved from http://www.toknowpress.net/ISBN/978-961-6914-07-9/papers/S3_29-47.pdf

Lin, J., Lu, Y., Wang, B., \& Wei, K. K. (2011). The role of inter-channel trust transfer in establishing mobile commerce trust. Electronic Commerce Research and Applications, 10(6), 615-625. http://doi.org/10.1016/j.elerap.2011.07.008

Linda, \& Lai, S. (2010). Social Commerce - E-Commerce in Social Media Context. Proceedings of World Academy of Science: Engineering \& Technology, 4(12), 8. http://doi.org/10.1145/2389376.2389382

Mayer R. C., Davis, J. H., \& Schoorman, F. D. (1995) An Integrative Model of Organizational Trust. The Academy of Management Review, 20(3), 709-734. http://www.jstor.org/stable/258792

Moorman, C., Deshpande, R., \& Zaltman, G. (1993). Factors Affecting Trust in Market Research Relationships. Journal of Marketing, 57(1), 81-101. http://www.jstor.org/stable/1252059 .

Petrovic, D., \& Kovacevic, I. (2012). Distrust as Obstacle to e-Commerce Development in Serbia. Management Journal for Theory and Practice Management 65, 71-77. DOI: 10.7595/management.fon.2012.0035

Rad, A. A., \& Benyoucef, M. (2011). A model for understanding social commerce. Information Systems Applied Research, 4(2), 63-73.

See-To, E. W. K., \& Ho, K. K. W. (2014). Value co-creation and purchase intention in social network sites: The role of electronic Word-of-Mouth and trust - A theoretical analysis. Computers in Human Behavior, 31(FEBRUARY), 182-189. http://doi.org/10.1016/j.chb.2013.10.013

Shi, S., \& Chow, W. S. (2015). Trust Development And Transfer In Social Commerce : Prior Experience As Moderator. Industrial Management \& Data Systems, 115(7), 1182-1203. http://doi.org/10.1108/02635570710734262

Teng, S., Khong, K. W., Goh, W. W., \& Chong, A. Y. L. (2014) . Examining The Antecedents Of Persuasive Ewom Messages In Social Media. Online Information Review, 38(6), 746 - 768. http://dx.doi.org/10.1108/OIR-04-2014-0089

Todri, V., \& Adamopoulos, P. (2014). Social Commerce : An Empirical Examination of the Antecedents and Consequences of Commerce in Social Network Platforms. Thirty Fifth International Conference on Information Systems, 1-18.

Wang, Y., Vassileva, J. (2003). Trust and Reputation Model in Peer-to-Peer Networks, Proc. of IEEE Conference on P2P Computing. Linkoeping, Sweden.

Wu, P. C. S., \& Wang, Y. C. (2011). The influences of electronic word of mouth message appeal and message source credibility on brand attitude. Asia Pacific Journal of Marketing and Logistics, 23(4), 448-472. http://doi.org/10.1108/13555851111165020

Xiayu, C., Qian, H., Davison, R. M., \& Zhongsheng H. (2015). What Drives Trust Transfer ? The Moderating Roles of Seller-Specific and General Institutional Mechanisms What Drives Trust Transfer? The Moderating Roles of Seller-Specific and General Institutional Mechanisms. International Journal of Electronic Commerce, 20(November 2015), 261-289. http://doi.org/10.1080/10864415.2016.1087828 